\title{
Purification and characterization of glutathione $S$-transferases from two syrphid flies (Syrphus ribesii and Myathropa florea)
}

\author{
Nicolas Vanhaelen*, Frédéric Francis, Eric Haubruge \\ Department of Pure and applied Zoology Department, Gembloux Agricultural University, Passage des Déportés 2, \\ Gembloux B-5030, Belgium
}

Received 26 May 2003; received in revised form 10 October 2003; accepted 10 October 2003

\begin{abstract}
Glutathione $S$-transferases (GST) play an important role in the detoxification of many substances including organic pollutants and plant secondary metabolites. We compared the GST of two syrphid species, the aphidophagous Syrphus ribesii and the saprophagous Myathropa florea to assess the relation between feeding type and GST patterns. Differences between the GST of the hoverfly species were observed after purification by affinity chromatography, SDS-PAGE and kinetic studies. While the specific activities of the purified enzymes were different, the purification yields were similar. The variation in specific activities was related to the presence of different isoenzymes in both syrphid species by SDSPAGE. While two bands of 24 and $32 \mathrm{kDa}$ were observed for $M$. florea, one more band of $26 \mathrm{kDa}$ was present in $S$. ribesii. When a range of substrate and glutathione concentrations was tested, differences in $K_{m}$ and $V_{\max }$ between the glutathione $S$-transferases from both hoverfly species were also observed. These results are discussed in terms of adaptations to the feeding habit and the habitat of the two syrphid species.
\end{abstract}

(c) 2003 Elsevier Inc. All rights reserved.

Keywords: Glutathione $S$-transferases (GST); Detoxification; Syrphus ribesii; Myathropa florea; Adaptation; Feeding type; Hoverflies

\section{Introduction}

Syrphid species can be found in very different habitats. While adults feed on nectar and pollen, larvae have various feeding behaviours. Most of them are aphidophagous with the remaining being species sapro- or coprophagous (Gilbert, 1986). Whether it is to cope with defence compounds sequestered by their prey in the aphidophagous species or to face organic compounds and pollutants found in their habitat for the sapro- and coprophagous species, they all need strong detoxification abilities.

\footnotetext{
*Corresponding author. Tel.: +32-81-622280; fax: +32-81622312 .

E-mail address: vanhaelen.n@fsagx.ac.be (N. Vanhaelen).
}

Among the different detoxifying enzymes, glutathione $S$-transferases or GST (EC 2.5.1.18) play a major role. GSTs are mainly cytosolic enzymes catalysing the nucleophilic attack by glutathione on the electrophilic centre of a range of endogenous or xenobiotic hydrophobic molecules (Boyland and Chasseaud, 1969). When conjugated to reduced glutathione (GSH) potentially toxic substances become more water soluble and generally less toxic (Grant and Matsumura, 1989). GSTs are important in insecticide resistance and are involved in the metabolism of organophosphorous and organochlorine compounds (Clark and Shamaan, 1984; Clark et al., 1984; Ranson et al., 1997). Other xenobiotics such as plant secondary metabolites induce GST activity in phytophagous insects, 
and similarly in predators that feed on these herbivores (Yu, 1982; Francis, 1999; Vanhaelen et al., 2001).

To determine the influence of larval habitat and feeding behaviour on GST patterns and properties we partially purified and characterized the GSTs of adult Syrphus ribesii and Myathropa florea. The first is, along with Episyrphus balteatus, one of the most common aphidophagous species found in northern Europe, while the second is an easily identifiable saprophagous species.

\section{Materials and methods}

\subsection{Chemicals}

1-Chloro-2,4-dinitrobenzene (CDNB) and 2,4dinitro-1-iodobenzene (DNIB) solutions were prepared in ethanol. GSH was used as a distilled water solution. All products were purchased from Fluka Chemicals and V.W.R. Company.

\subsection{Insects}

$S$. ribesii and $M$. florea adults were caught with a net in the botanical garden of the Gembloux University.

\subsection{Determination of protein concentration and glutathione S-transferases activity}

GST activity was determined according to Habig et al. (1974) using a $20 \mathrm{mM}$ sodium phosphate buffer, pH 6.8 and CDNB and DNIB as benzene substrates. Three replicates were used for each measure. The protein concentration of homogenates was determined by the method of Lowry et al. (1951). Two replicates were used for each experiment, using bovine serum albumin as a standard. A Shimadzu UV-160A spectrophotometer was used for protein and enzymatic measurements.

\subsection{Purification of enzyme}

Whole syrphids $(2 \mathrm{~g})$ were homogenized at 4 ${ }^{\circ} \mathrm{C}$ in a blender in $10 \mathrm{ml} 20 \mathrm{mM}$ sodium phosphate buffer, $\mathrm{pH}$ 6.8. The homogenate was then centrifuged $(90 \mathrm{~min}, 100000 \times g)$ and the supernatant was applied to a PD10 column (Pharmacia) before an affinity column $(5 \mathrm{ml})$. The latter was packed with epoxy-activated glutathione-agarose (Sigma). The column was washed with $15 \mathrm{ml}$ phosphate buffer, then eluted with $50 \mathrm{mM}$ Tris- $\mathrm{HCl}$ buffer (pH 9.6) in which the purified enzyme was collected and subsequently used for kinetics and electrophoretic studies.

\subsection{Enzyme kinetics}

Enzyme kinetics were determined for GSH and benzene substrates (CDNB and DNIB) by recording the activity towards a range of concentrations of GSH $(0.01-0.10 \mathrm{mM})$ or benzene substrates $(0.005-0.050 \mathrm{mM})$, while the concentration of the other substrate was kept constant at $0.02 \mathrm{mM}$ or $0.1 \mathrm{mM}$ of CDNB or GSH, respectively. Maximal velocity $V_{\max }$ and Michaelis constant $K_{m}$ values for each substrate were determined from Lineweaver-Burk plots.

\subsection{Polyacrylamide gel electrophoresis (PAGE/ SDS-PAGE)}

For the native gel electrophoresis, samples were loaded with glycerol on separation gels that were $10 \%$ acrylamide in $0.5 \mathrm{M}$ Tris- $\mathrm{HCl} \mathrm{pH} 8.8$. Stacking gels were $3.5 \%$ acrylamide in $1.5 \mathrm{M}$ Tris-HCl pH 6.8.

For SDS-PAGE samples were diluted 1:4 with a solubilizer (1\% SDS; $0.02 \%$ bromophenol; $1 \%$ $\beta$-mercaptoethanol in running buffer) and boiled for $3 \mathrm{~min}$ before electrophoresis. Separation gels were $10 \%$ acrylamide $/ 0.01 \%$ SDS in $0.5 \mathrm{M}$ Tris$\mathrm{HCl} \mathrm{pH} \mathrm{8.8.} \mathrm{Stacking} \mathrm{gels} \mathrm{were} 3.5 \%$ acrylamide in $1.5 \mathrm{M}$ Tris- $\mathrm{HCl} \mathrm{pH}$ 6.8. The Laemmli (1970) discontinuous buffer system was used. Electrophoresis was carried out at $45 \mathrm{mV}$ and $20 \mathrm{~mA}$ overnight. The gels were stained with Bio-Rad's silver staining kit according to the manufacturer's instructions.

\section{Results}

The yields of purification of GST for the two syrphids were $78 \%$ and $66 \%$ of the total CDNB activity collected after GSH-affinity chromatography for $M$. florea and $S$. ribesii, respectively, (Table 1). The specific GST activities towards CDNB and DNIB, respectively, were $1.79 \pm 0.04$ and $0.13 \pm 0.03 \mu \mathrm{mol} \mathrm{min} \mathrm{mg}^{-1} \mathrm{mg}^{-1}$ for florea 
Table 1

Purification of glutathione $S$-transferases from $S$. ribesii and $M$. florea (substrates: CDNB $0.02 \mathrm{mM}$ and GSH $0.1 \mathrm{mM}, 2 \mathrm{~g}$ of insect used)

\begin{tabular}{lcccc}
\hline & Protein $(\mathrm{mg} / \mathrm{ml})$ & Specific activity $\left(\mathrm{nmol} \mathrm{min} \mathrm{mg}^{-1}\right)$ & Percentage of recovery & Fold purification \\
\hline S. ribesii & & & & 100 \\
Homogenate & $234 \pm 8$ & $86 \pm 3$ & & 1 \\
After PD10 & $157 \pm 9$ & $205 \pm 16$ & 65.7 & 2.5 \\
Bound fraction & $4 \pm 1$ & $3072 \pm 36$ & & \\
M. florea & & $63 \pm 7$ & 100 & 1 \\
Homogenate & $335 \pm 12$ & $883 \pm 23$ & 77.7 & 14.1 \\
After PD10 & $201 \pm 10$ & $1789 \pm 42$ & & 28.5 \\
Bound fraction & $3 \pm 1$ & & \\
\hline
\end{tabular}

For measurements related to GSH, the concentration varied from 0.01 to $0.1 \mathrm{mM}$ while CDNB concentration was kept constant at $0.02 \mathrm{mM}$. For measurements related to benzene substrates (CDNB and DNIB), the concentrations ranged from 0.005 to $0.05 \mathrm{mM}$ while GSH concentration was kept constant at $0.1 \mathrm{mM}$.

and $3.07 \pm 0.04$ and $1.27 \pm 0.07 \mu \mathrm{mol}^{-1} \mathrm{~min}^{-1}$ $\mathrm{mg}^{-1}$ for $S$. ribesii. GST differences between the two hoverflies were also observed for kinetic parameters. GSTs of $S$. ribesii have higher affinities for all three tested substrates (Table 2).

The affinity bound fractions were used without further purification for SDS-PAGE electrophoresis. For $M$. florea silver staining revealed two GST bands. The molecular mass of the band is estimated at approximately 24 and $32 \mathrm{kDa}$ when compared to the molecular marker used. There is one more band for $S$. ribesii, at approximately $26 \mathrm{kDa}$. (Fig. $1)$.

Native gel electrophoresis was also carried out and revealed that there was only one heterodimeric isoenzyme for $M$. florea while four isoforms can be observed in $S$. ribesii. The molecular masses of the bands are estimated between 50 and $64 \mathrm{kDa}$ (Figure 2).

\section{Discussion}

Though the dipteran GSTs are well studied, little is known about these detoxification enzymes in the syrphid family that accounts for important pollinators and natural enemies used in aphid biological control. After centrifugation and before affinity chromatography, the supernatant was applied to a PD10 column to suppress the low molecular weight inhibitors present in homogenates while maintaining GST activity. The amount of enzymes bound to the column was $10 \%$ lower for $S$. ribesii compared to $M$. florea for which $77 \%$ of the activity was accounted for. Such yields were also obtained for Adalia bipunctata (Francis et al., 2002) and Aedes aegypti, (Grant and Matsumura, 1989) while they were much lower for Trichoplusia ni and Tenebrio molitor at 26\% and 34\%, respectively, (Yu, 1989; Kostaropoulos et al., 1996). The degrees of purification were twice as high as those reached for T. ni, Spodoptera frugiperda and T. molitor, however, much lower than for Nilaparvata lugens and Anopheles dirus (Yu, 1989; Kostaropoulos et al., 1996; Prapanthadara et al., 1996; Vontas et al., 2002). The specific activity of the affinity purified GST toward CDNB was 1.7-fold higher for $S$. ribesii. Important differences were also observed when considering the kinetics

Table 2

Kinetic properties of GST from S. ribesii and M. florea

\begin{tabular}{|c|c|c|}
\hline Property & M. florea & S. ribesii \\
\hline$K_{m}$ toward CDNB $(\mathrm{mM})$ & 0.409 & 0.294 \\
\hline$V_{\max }$ toward CDNB $\left(\mu \mathrm{mol} \mathrm{min}-1 \mathrm{mg}^{-1}\right)$ & 0.273 & 1.436 \\
\hline$K_{m}$ toward DNIB $(\mathrm{mM})$ & 0.345 & 0.097 \\
\hline$V_{\max }$ toward DNIB $\left(\mu \mathrm{mol} \mathrm{min} \mathrm{mg}^{-1} \mathrm{mg}^{-1}\right)$ & 0.260 & 0.322 \\
\hline$K_{m}$ toward GSH $(\mathrm{mM})$ & 0.474 & 0.384 \\
\hline 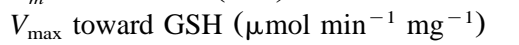 & 0.268 & 0.941 \\
\hline
\end{tabular}


(a)

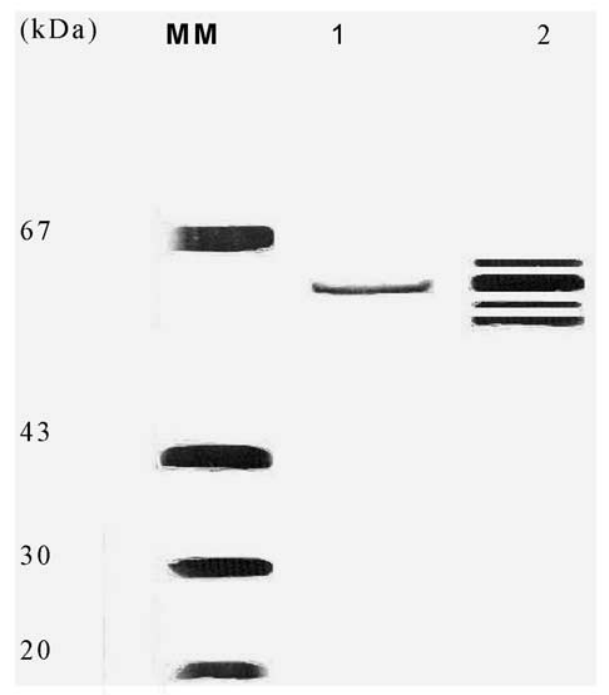

(b)

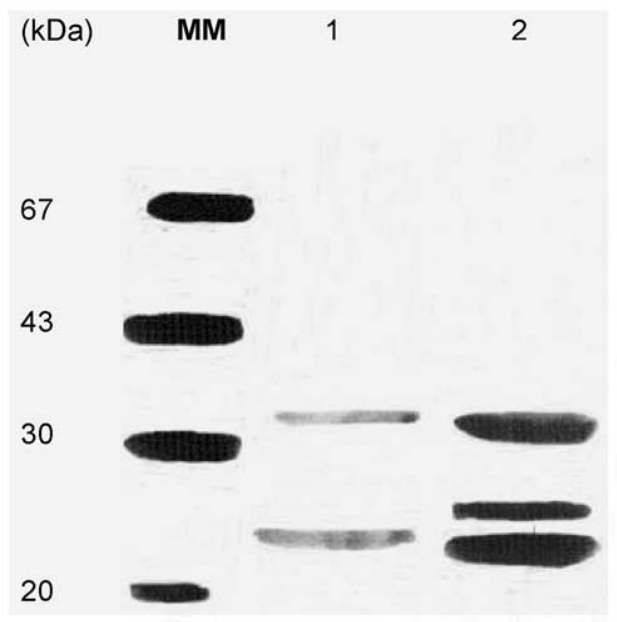

Fig. 1. (a) PAGE of purified GSTs from M. florea (lane 1) and Syrphus ribesii (lane 2 ) on a $12 \%$ polyacrylamide gel. The sizes $(\mathrm{kDa})$ of molecular mass markers (MW) are indicated. (b) SDS-PAGE of purified GSTs from $M$. florea (lane 1) and S. ribesii (lane 2 ) on a $12 \%$ polyacrylamide gel. The sizes $(\mathrm{kDa})$ of molecular mass markers (MW) are indicated.

assays. For the three tested substrates $M$. florea had higher $K_{m}$ than those from $S$. ribesii, with values, respectively, 2.6, 1.4 and 2 fold higher for GSH, CDNB and DNIB. The $V_{\max }$ values were always higher for $S$. ribesii with ratios of 3.2, 5.3 and 1.8 for GSH, CDNB and DNIB when compared to the other tested species.
SDS-PAGE confirmed earlier differences. While two bands were observed for $M$. florea at 24 and $32 \mathrm{kDa}$, one more band was present at $26 \mathrm{kDa}$ for the aphidophagous hoverfly. The molecular masses are in the same range as those for GST from domestic flies, fruit flies, mosquitoes and beetles (Clark and Shamaan, 1984; Grant and Matsumura, 1989; Fournier et al., 1992; Kostaropoulos et al., 1996; Francis et al., 2002). GSTs are known to exist in dimers (homo and heterodimers) (Grant and Matsumura, 1989). While one heterodimer could be observed for $M$. florea, four were present in S. ribesii. From the comparison of SDS and native gels, it appears that there is one homodimer and three heterodimers. The masses of the native enzymes vary between 50 and $64 \mathrm{kDa}$, which is in accordance with previous work (Fournier et al., 1992).

The difference observed in isoenzymatic composition between the hoverflies may be responsible for the different, but overlapping, substrate specificities as observed in other species (Kostaropoulos et al., 1996; Yu, 2002). These specificities seem to be confirmed by the ratio between activities toward CDNB and DNIB. In a previous paper, we reported that a ratio of two between the activities with CDNB and DNIB for aphidophagous species while a ratio of one was obtained for the representatives of other feeding habits (Vanhaelen et al., 2001). The purification of GST from an aphidophagous and a saprophagous species confirms these ratios. These findings indicate a link between the regime of their offspring and their detoxification abilities. The two isoforms present in both species are certainly responsible for the detoxification of common xenobiotics while the isoform only present in the aphidophagous species are probably an adaptation to cope with chemicals specific to its environment and prey. The compounds frequently encountered by $S$. ribesii include pesticides that are known to induce GST activity (Clark et al., 1986; Hemingway et al., 1991; Kostaropoulos et al., 2001). Other compounds that this species has to face are plant allelochemicals. These defence compounds emitted by plants could act directly or through the hoverfly's prey. Indeed, aphids often sequester these plant secondary metabolites to protect themselves against their predator (Emrich, 1991; Dobler, 2001; Francis et al., 2001). The efficacy of the aphid defence depends on the detoxification ability of its predator. The ladybird A. bipunctata is very sensitive to 
the isothiocyanates produced by the cabbage aphid Brevicoryne brassicae as its GSTs saturate quickly whereas the hoverfly E. balteatus GSTs allow it to feed on that prey (Francis et al., 1999; 2000; Vanhaelen et al., 2001; 2002).

To determine more accurately the role of these different isoenzymes, the induction of GSTs with chemicals frequently encountered in the habitat and diet of both species are in progress. Such studies will help in understanding the exact role in detoxification of the various isoenzymes during various life stages of a certain species and to understand the evolutionary aspects of detoxification related to the habitat and feeding behaviour of each insect species.

\section{Acknowledgments}

This work was supported by a Ph.D. grant to the first author, awarded by the Fonds pour la formation à la Recherche dans l'Industrie et l'Agriculture.

\section{References}

Boyland, E., Chasseaud, L.E., 1969. The role of glutathione and glutathione $S$-transferases in mercapturic acid biosynthesis. Adv. Enzymol. 32, 173.

Clark, A.G., Shamaan, N.A., 1984. Evidence that DDT-dehydrochlorinase from the house fly is a glutathione $S$-transferase. Pest. Biochem. Physiol. 22, 249-261.

Clark, A.G., Shamaan, N.A., Dauterman, W.C., Hayaoka, T., 1984. Characterization of multiple glutathione $S$-transferases from the housefly, Musca domestica (L). Pest. Biochem. Physiol. 22, 51-59.

Clark, A.G., Shamaan, N.A., Sinclair, M.D., Dauterman, W.C., 1986. Insecticide metabolism by multiple glutathione $S$ transferases in two strains of the housefly, Musca domestica (L). Pest. Biochem. Physiol. 25, 1969.

Dobler, S., 2001. Evolutionary aspects of defense by recycled plant compounds in herbivorous insects. Basic Appl. Ecol. 2, 15-26.

Emrich, B.H., 1991. Erworbene Toxizität bei der Lupinenblattlaus Macrosiphum albifrons und ihr Einfluss auf die aphidophagen Prädatoren Coccinella septempunctata, Episyrphus balteatus und Chrysoperla carnea. Zeit. Pflanzenk. Pflanzen. 98, 398-404.

Fournier, D., Bride, J.M., Poirie, M., Bergé, J.B., Plapp, F., 1992. Glutathione $S$-transferase. Biochemical characteristics of major form from houseflies susceptible and resistant to insecticides. J. Biol. Chem. 267, 1840-1845.

Francis, F., 1999. Conséquences évolutives des relations entre le puceron et son prédateur en présence de substances allélochimiques chez les Brassicaceae. 5ème Conférence Internationale sur les ravageurs en agriculture, Montpellier, France, ANPP.
Francis, F., Broon, D., Haubruge, E., 1999. Studies of the glutathione $S$-transferases activities and their localisation in Adalia bipunctata (Coleoptera: Coccinellidae). Med. Fac. Landbouww. Univ. Gent 64/3a, 349-355.

Francis, F., Haubruge, E., Gaspar, C., 2000. Influence of host plants on specialist/generalists aphids and on the development of Adalia bipunctata (Coleoptera: Coccinellidae). Eur. J. Entomol. 97, 481-485.

Francis, F., Lognay, G., Wathelet, J.P., Haubruge, E., 2001. Effects of allelochemicals from first (Brassicaceae) and second (Myzus persicae and Brevicoryne brassicae) trophic levels on Adalia bipunctata. J. Chem. Ecol. 27, 243-256.

Francis, F., Haubruge, E., Dierickx, P., 2002. Glutathione $S$ transferase isoenzymes in the two-spot ladybird, Adalia bipunctata (Coleoptera: Coccinellidae). Arch. Insect Biochem. Physiol. 49, 158-166.

Gilbert, F.S., 1986. Hoverflies. Cambridge University Press, Cambridge.

Grant, D.F., Matsumura, F., 1989. Glutathione $S$-transferase 1 and 2 in susceptible and insecticide resistant Aedes aegypti. Pest. Biochem. Physiol. 33, 132-143.

Habig, W.H., Pabst, M.J., Jakoby, W.B., 1974. Glutathione $S$ transferases: the first enzymatic step in mercapturic acid formation. J. Biol. Chem. 249, 30-71.

Hemingway, J., Miyamoto, J., Herath, P.R.J., 1991. A possible novel link between organophosphorous and DDT insecticide resistance genes in Anopheles supporting evidence from fenitrothion metabolism studies. Pest. Biochem. Physiol. 39, 49-56.

Kostaropoulos, I., Mantzari, A.E., Papadopoulos, A.I., 1996. Alterations of some glutathione $S$-transferase characteristics during the development of Tenebrio molitor (Insecta: Coleoptera). Insect Biochem. Mol. Biol. 26, 963-969.

Kostaropoulos, I., Papadopoulos, A.I., Metaxakis, A., Boukouvala, E., Papadopoulos-Mourkidou, E., 2001. Glutathione $S$ transferase in defence against pyretroids in insects. Insect Biochem. Mol. Biol. 31, 313-319.

Lowry, O.H., Rosebrough, N.J., Farr, A.L., Randall, R.J., 1951. Protein measurement with the folin phenol reagent. J. Biol. Chem. 193, 265-275.

Prapanthadara, L., Koottathep, S., Promtet, N., Hemingway, J., Ketterman, A.J., 1996. Purification and characterization of a major glutathione $S$-transferase from the mosquito Anopheles dirus (Species B). Insect Biochem. Mol. Biol. 26, 277-285.

Ranson, H., Prapanthadara, L.A., Hemingway, J., 1997. Cloning and characterisation of two glutathione S-transferases from a DDT-resistant strain of Anopheles gambiae. Biochem. J. 324, 97-102.

Vanhaelen, N., Haubruge, E., Lognay, G., Francis, F., 2001. Hoverfly glutathione $S$-transferases and effect of Brassicaceae secondary metabolites. Pest. Biochem. Physiol. 71, 170-177.

Vanhaelen, N., Gaspar, C., Francis, F., 2002. Influence of prey host plant on a generalist aphidophagous predator: Episyrphus balteatus (Diptera: Syrphidae). Eur. J. Entomol. 99, 561-564. 
Vontas, J.G., Small, G.J., Nikou, D.C., Ranson, H., Hemingway, J., 2002. Purification, molecular cloning and heterologous expression of a glutathione $S$-transferase involved in insecticide resistance from rice brown planthopper, Nilaparvata lugens. Biochem. J. 362, 329-337.

Yu, S.J., 1982. Host plant induction of glutathione $S$-transferases in the fall armyworm. Pest. Biochem. Physiol. 17, $59-66$.
Yu, S.J., 1989. Purification and characterization of glutathione $S$-transferases from five Phytophagous Lepidoptera. Pest. Biochem. Physiol. 35, 97-105.

Yu, S.J., 2002. Substrate specificity of glutathione $S$-transferases from the fall armyworm. Pest. Biochem. Physiol. 74, $41-51$. 